\title{
Reconstructing Cultural Heritage in Conflict Zones: Should Palmyra be Rebuilt?
}

\author{
Nour A. Munawar \\ University of Amsterdam
}

\begin{abstract}
Cultural heritage has fallen under the threat of being of damaged and/or erased due to armed conflicts, and destruction has increasingly become a major part of daily news all over the world. The destruction of cultural heritage has escalated in Syria as the ongoing armed conflict has spread to World Heritage Sites, such as Palmyra and the old city of Aleppo. The devastation of Syria's war has deliberately and systematically targeted archaeological monuments dating from the prehistoric, Byzantine, Roman, and Islamic periods, with no distinction being made of the cultural, historical, and socio-economic significance of such sites. The violence of this conflict is not, of course, limited to the destruction of cultural property, and has first and foremost served to introduce nonstate radical actors, such as Daesh, who targeted local people, archaeological site, museum staff and facilities.

The destruction and re-purposing of monuments in Syria, such as Daesh's attempts to turn churches into mosques, are heavy-handed attempts to re-write history by erasing physical evidence. In this paper, I explore the semantics of continuous attempts to reconstruct cultural heritage sites, destroyed by Daesh, during the ongoing war, and how the destruction and reconstruction of Syria's heritage have been deployed to serve political agendas.
\end{abstract}

Keywords: Palmyra, Syria, Conflict, Reconstruction, Cultural heritage

\section{Introduction}

The World Heritage Site of Tadmur - the Arabic name of Palmyra - or as it is known in Syria "the bride of the desert" has been in danger ever since the crisis in Syria turned into an armed conflict at the end of 2011. Palmyra has been part of the World Heritage List since 1980, and was included in the list of World Heritage sites in danger in 2013, alongside five other World Heritage Sites in Syria. In September 2015, the United Nations confirmed that jihadists of Daesh had blown up the Bel-Temple of Palmyra, which dates back to $32 \mathrm{CE}$. Shortly after this the official Syrian army confirmed that Palmyra had, after weeks of intense combat, been recaptured, and that the Directorate General of Antiquities and Museums in Syria had begun preparing plans to restore and reconstruct what had been destroyed. Although the destruction of Palmyra has been well-documented by activists since the beginning of Syria's armed conflict, the speed at which Palmyra's Arch of Triumph was restored has astonished many archaeologists and observers of cultural heritage. In the meantime, a replica of Palmyra's Arch of Triumph 
of Palmyra has been erected in Trafalgar Square in London, and has garnered mixed reviews in the media.

In this paper, I seek to answer the questions opened by these reactions, and the symbolic character of this specific monument. The heritage gaze is partial and selective (Harrison 2010). Some have asked, why Aleppo's Umayyad Mosque minaret - which was destroyed in April 2012 - or the ancient gates of Nimrud and Nineveh in Iraq, which suffered at the hands of Daesh, have not been reconstructed? This question triggers larger questions regarding the parameters of heritage reconstruction as practice; is it not through the process of decay and loss that monuments are incorporated into the archaeological record? Furthermore, is not damage and/or destruction just another phase in the life-history of a monument, albeit a less than positive one in terms of longterm preservation?

This paper explores the different stakeholders and what their interests in Palmyra are, such as from local people, and how each stakeholder values and perceives the World Heritage Site. The interests of the stakeholders are studied based on how each stakeholder has dealt with Palmyra's ruins and what tools and methods have been deployed to gain the legitimacy of controlling the site. This paper aims to investigate how the destruction of Palmyra's heritage - during Syria's conflict - has been represented in the media reports and academia, and how the destruction affected Palmyra and the reconstruction plans.

Finally, I will discuss the issues that need to be considered when attempts are made to restore monuments in a place of ongoing conflict, such as the perimeter of Palmyra. In my view, no rebuilding or restoration plans can be safeguarded at this stage of Syria's unfinished war and it is wrong to believe that even state of the art modern restoration technologies can in some way replicate or recreate the authenticity of a contested heritage.

\section{Palmyra and Syria's Conflict}

Cultural cleansing, destruction, demolition, deterioration, damage, ruination and several other negative terms that indicate the erasing of parts or complete heritage sites have become the keywords which characterize cultural heritage discourse in the early twentieth-first century. This trend has been confronted by optimistic - and sometimes naïve - reactions that were led by "positivist" scholars and the international community to promote a responsive language, such as the reconstruction, rebuilding, restoration, protection, and preservation of cultural heritage sites (for further discussion see Kealy 2016). Amidst this negative and positive collection of terms, cultural heritage sites are still being destroyed and conflict does not show mercy towards cultural heritage. Skimming through the history of cultural heritage destruction after the Second World War shows that the ongoing conflicts in Syria and Iraq, alongside the Balkan Wars (Abazi 2004), are those most characterized by cultural annihilation. Since the Syrian and Iraqi conflicts have shared the old/new enemy of human tolerance Daesh, these 
conflicts became asymmetric and showed the weakness and ineffectiveness of the international community and the West in particular in dealing with such conflicts on several levels (Pecht 2016).

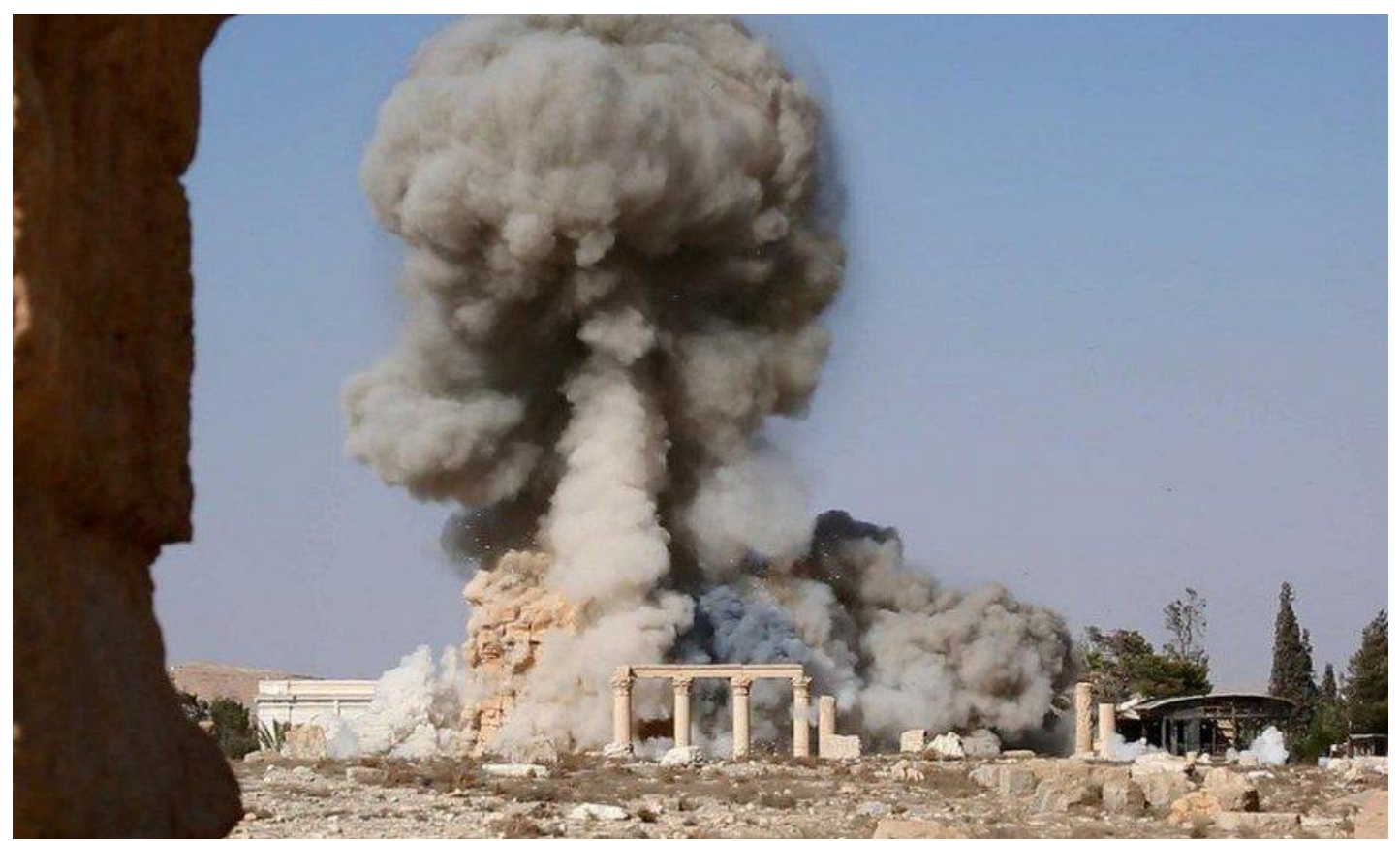

Figure 1. Baal-Shamin, The Guardian, 25 August 2016.

Fears and concerns have rapidly grown after Daesh seized control over the World Heritage Site of Palmyra, or as it is known "The Venice of the Sand", in May 2015 and after two weeks of fighting with the Syrian government army. Social media platforms started to recirculate videos and pictures of the jihadi militia destroying the artifacts of the Mosul museum to bring the attention to the fact that Palmyra might shortly face a similar fate. $23^{\text {rd }}$ August 2015 is the date that has been engraved in the memory of all of humanity and particularly the memory of the Syrian people. On that day, the series of "iconoclastic" destruction of monuments started when Daesh blew up the 2,000-yearold Baal-Shamin (Fig. 1) temple of the World-famous Greco-Roman site of Palmyra (Macfarlan 2015; Melvin, et al. 2015). This destruction was followed by the destruction of one of the most significant temples in the Middle East, Temple of Bel, which dates back to the $1^{\text {st }}$ century CE. Less than two weeks later, the radical jihadists destroyed Palmyra's Roman monument, Arch of Triumph (Fig. 2), which dates back to the $3^{\text {rd }}$ century CE. Besides that, Daesh vandalism has extended to the staff who work(ed) on protecting Palmyra's museum and buildings. In a move which shocked the international audiences they also beheaded Khaled al-Asaad, who was formerly the enthusiastic Head of Antiquities in Palmyra for 40 years, because he refused to lead Daesh fighters to Palmyra's hidden antiquities (Hubbard 2015; Shaheen 2015a).

\footnotetext{
${ }^{1}$ Both The Venice of the Sand and "the bride of the desert" have been used in literature to describe Palmyra. While the Venice of the Sand is more popular in the West, the "the bride of the desert" is popular in Syria.
} 
Media reports promptly surfaced to cover all these incidents which occurred in less than 4 months of Daesh control of Palmyra; ignoring - together with the international community - that Palmyra had been threatened before the Daesh offensive attack to control the city according to several UNESCO, ICOMOS, etc. condemning statements to stop the violence in the perimeter of the World Heritage Site (Nakasis a\&nd Lianos 2015, UNESCO 2013; 2014).

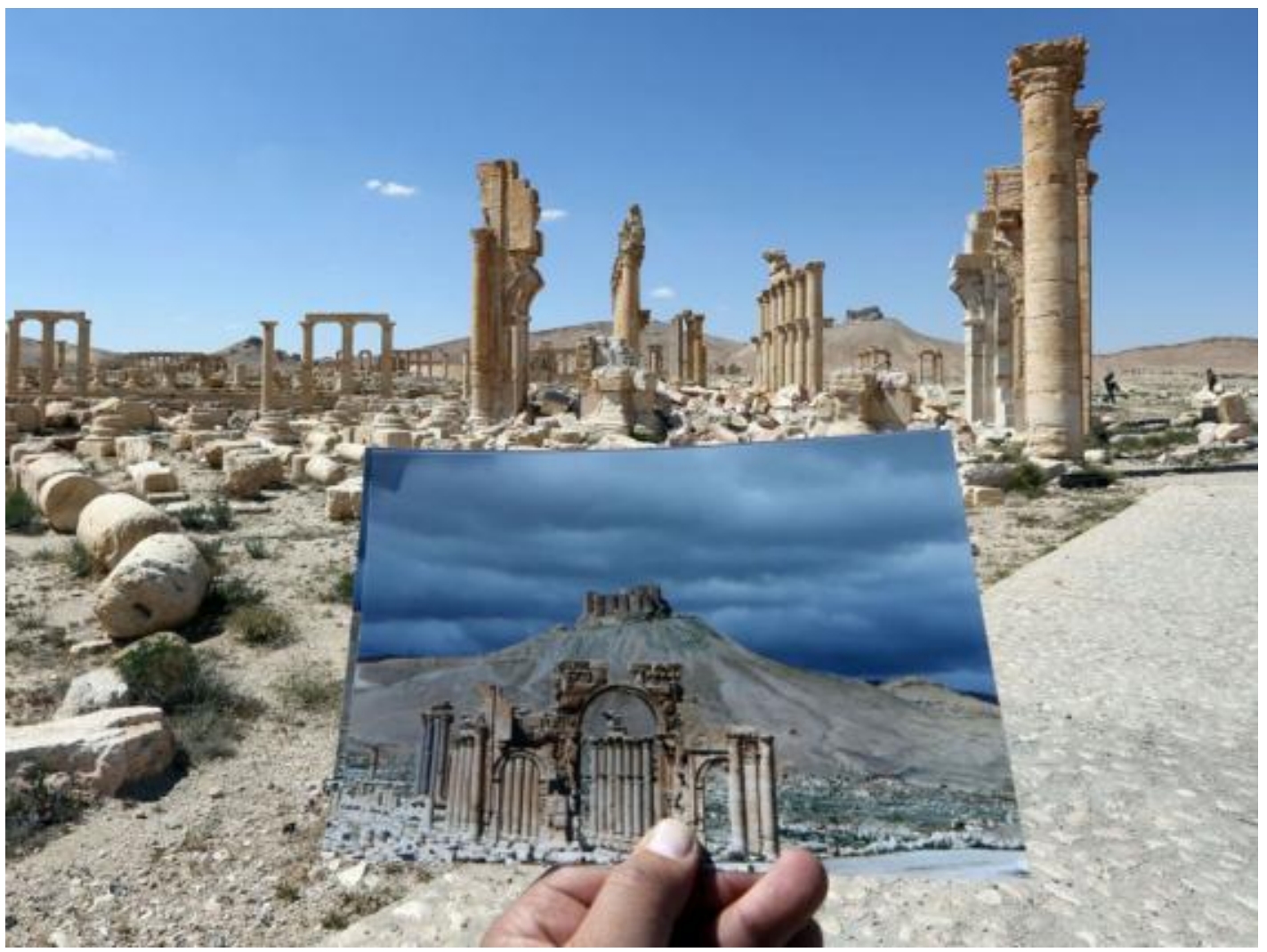

Figure 2. Arch of Triumph of Palmyra, Joseph Eid-Getty Images, 31 March 2016

Since the beginning of the Syrian conflict, Palmyra has sustained several types of damage, such as looting, collateral damage, army occupation, and damage from weapons fired by the opposed fighters (Cunliffe 2012). The United Nations has urged all parties to protect Palmyra and to immediately stop the military actions in the heritage sites. A statement issued by United Nations Secretary-General Ban Ki-moon and UNESCO Director-General Irina Bokova reads:

(...) World Heritage sites have suffered considerable and sometimes irreversible damage. Four of them are being used for military purposes or have been transformed into battlefields: Palmyra; the Crac des Chevaliers; the Saint Simeon Church in the Ancient villages of Northern Syria; and Aleppo, including the Aleppo Citadel..." (United Nations 2014). ${ }^{2}$

\footnotetext{
${ }^{2}$ See also Statement by UN Secretary-General Ban Ki-moon, UNESCO Director-General Irina Bokova and UN and League of Arab States Joint Special Representative for Syria Lakhdar Brabimi: The destruction of Syria's cultural heritage must stop. UN online, accessed 09 Nov 2016, http://www.un.org/sg/statements/index.asp?nid=7521
} 
AFP (Agence France-Presse) reported the destruction of Palmyra and confirmed that machine gun fire had directly affected the area of Palmyra (AFP 2012). Similarly, Maamoun Abdulkarim, director of Directorate-General of Antiquities and Museums (DGAM) in Syria has stated that the Syrian official army had troops in the archaeological site of Palmyra (Holmes 2013).

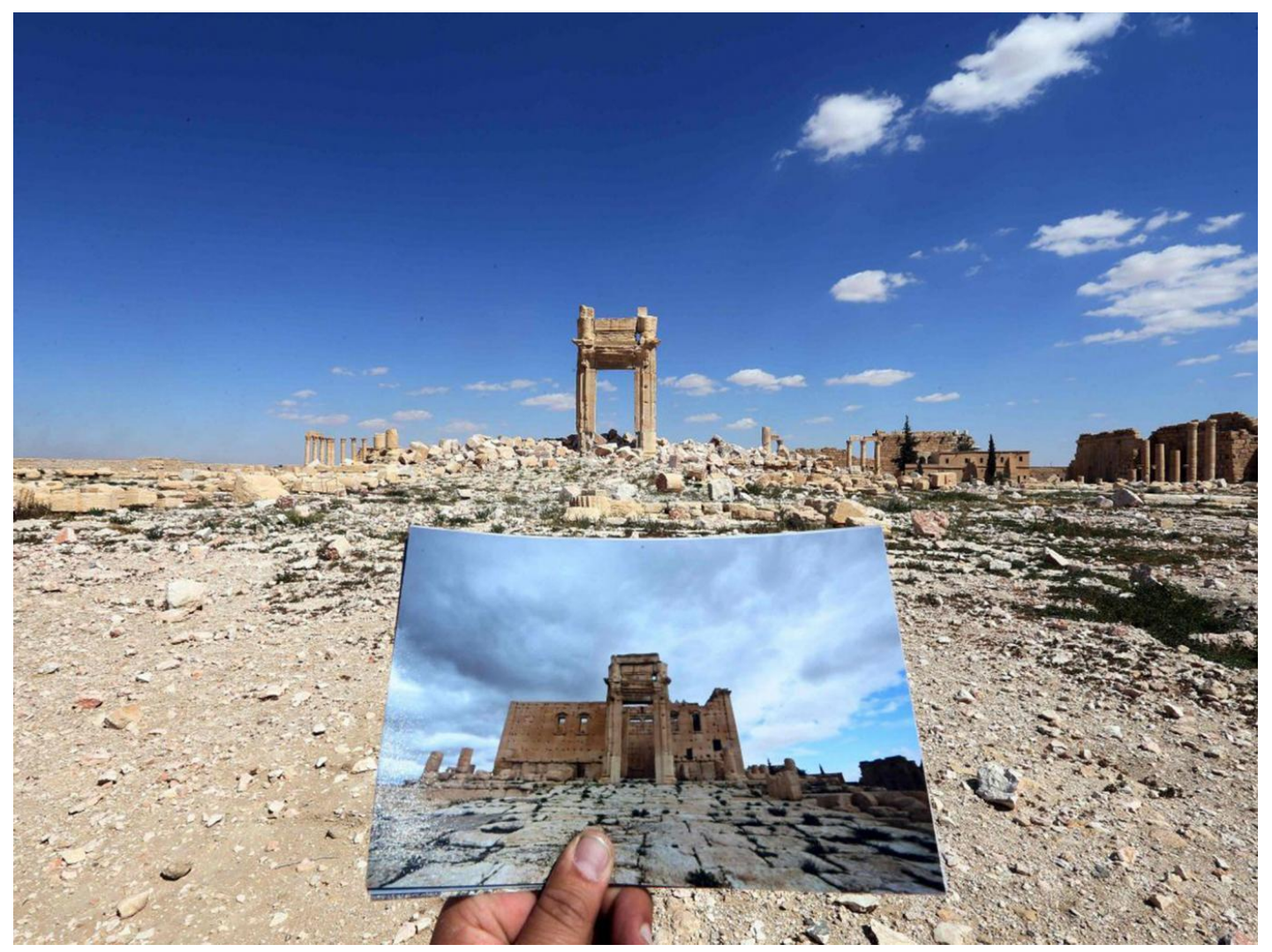

Figure 3. Temple of Bel, Joseph Eid-Getty Images, 31 March 2016

In a later stage of the conflict, the media promoted the recapture of Palmyra by the Russian-backed Syrian army as a "liberation" of the World Heritage Site. This incident triggered significant debates, starting with the question of how objective the media was when they had only chosen to report the damage that had been inflicted by Daesh fighters on heritage sites in Palmyra, Nimrud and Nineveh. Are Daesh the only "bad guys" in the Syrian and Iraqi conflicts? What are the implications of the Syrian's government vow to "rebuild" Palmyra immediately after the jihadi group withdrew and even though the war in Syria is still escalating? And can the state-promises or the modern-art restoration technologies in some way replicate or recreate the authenticity of a contested heritage? And if so, who should decide what and when? And to what extent should the promised "reconstruction" happen?

\section{Who Cares About Palmyra, and Why?}

The significance of Palmyra comes from its long history as a cultural heritage attraction, which has granted the city a special status among the archaeological sites that have been 
selected to represent the cradle of civilizations in the Middle East. Palmyra has witnessed periods of occupation and rule by several foreign kingdoms and empires which have ruled the Levant and Mesopotamia. The site of Palmyra is one of the few oases in the Syrian desert, and this allowed Palmyra to gain wealth and to rise to prominence as merchants ran trade caravans through the Silk Road. The construction of monumental buildings increased the splendour and grandeur of Palmyra, starting with the Temple of Bel (Fig. 3), the Great Colonnade, Baal-Shamin temple, etc. These monuments were influenced by the Greco-Roman civilization and they have distinguished Palmyra with distinctive art and architecture which combines western and eastern traditions (For further discussion, see also: Teixidor 2015).

My main aim in this paper is to clarify the importance of Palmyra from the point of view of different stakeholders who each claim a right to share the ancient monuments of Palmyra ${ }^{3}$. The multicultural, economic and socio-cultural values (Mason 2002) of Palmyra encouraged invaders to seize the city and claim its stewardship in order to benefit from its wealth, prosperity and geo-political dimensions. Palmyra's advantages caused it to become what an Arabic metaphor describes as the "king's cake" (كعكة الملك), and it is certain that there will be continuing efforts by regional, national, and also international powers to control this high status site. But from my perspective I believe that the immediate stakeholders in Palmyra are the local people - the Syrians - who were born in, and lived, and participated in constructing Palmyra's fame throughout history.

Viejo-Rose and Stig Sørensen (2015) consider that conflict and social disorder result in severe damage and the loss of irreplaceable and unique things in addition to psychologically affecting people who are linked to such sites. The importance of Palmyra for local people lies in it being part of their ancestors' heritage and memories, regardless of their religion or ethnicity. Palmyra is a place that all Syrians feel proud of and its remembrance has enhanced a sense of cultural identity (Holtrof 2015) which is one of the few things that unifies Syrians during the current war, which has torn Syrian society apart. In addition to this deeply rooted national significance, Zenobia, the Queen of Palmyra, represents the strength of the Syrian women and her leadership, will and wisdom have made her a symbol of feminism in the Arab World (Booth 2011).

The central and strategic location of Palmyra - midway between Syria and Iraq - has encouraged armed opposition groups to attempt to control the city ever since the beginning of the conflict in Syria, in 2011. Concurrently, the Syrian government sought to protect the capture of the city by all possible means, despite the fact that such military actions were themselves considered to be violations which threatened the World Heritage Site of Palmyra (Cunliffe 2012). The fact that both parties in the conflict wished to gain control over the site - prior to the emergence of Daesh - is not an indication that they wished to protect the archaeological heritage, but rather a sign that

\footnotetext{
3 Tadmur is the native name of Palmyra and it was first attested during the beginning of the Second millennium BCE. Scholars are still arguing about the origins of the name Tadmur whether it is Semitic or Hurrian. When Palmyra became part of the Roman Empire the site was named Palmyra during the first century CE, which came originally from the palm trees that were surrounding Palmyra (see also, O'Connor 1988).
} 
they believed that control of Palmyra would boost their popular support and would allow then to present themselves as protectors of Syria's fragile heritage (For further discussion about motives for targeting cultural property during armed conflict, see Brosché, et al. 2017).

The escalation of the war in Syria's war introduced non-state radical combatants (for further discussion about non-state armed groups, see Hausler 2016) - such as Al-Nusra Front and Daesh - who in a later stage also sought to control Palmyra. Palmyra was eventually taken by the self-proclaimed Islamic State in May 2015 (Shaheen 2015b). The radical fighters of Daesh focus primarily on the cultural cleansing of the areas that they control - they raze ancient sites as a whole even though such sites are often considered to be holy places for Islamic groups who oppose Daesh ideology and beliefs ${ }^{4}$, such as Sufi and Shia shrines and cemeteries (Zorich 2016).

Daesh has produced several videos and images of the destruction of monumental buildings in Palmyra, claiming that the buildings had been used to promote infidelity and therefore should be demolished (for further discussion about the links between terrorism and heritage destruction, see Meskell 2005). Scholars have seen Daesh videos and photos (BBC 2015; Tharoor 2015; Hall 2015; Wintour 2016) as documentary materials in which radical fighters were identified as iconoclasts (Harmanşah 2015). Daesh's interest in Palmyra was not based solely on ideological perspectives of destroying any non-Muslim heritage, however. Their interest lies in several factors, such as gaining more popularity and legitimacy by "reviving" the historical enactment of the destruction of idols when Muslims destroyed all the 360 idols that surrounded Kaaba when they conquered Mecca during the $7^{\text {th }}$ century CE (Donner 2014). By visibly destroying "idols" in Palmyra, Hatra and Mosul museum Daesh were attempting to gain attention and recruit further volunteers to their ranks. Another factor that needs to be taken into consideration is that Daesh were attempting to erase the extraordinary collective identity and memory of Palmyra in a way that would facilitate creating a new identity and memory of the place to represent the new population of Daesh. The latter can be evidently seen in the enslavement and massacring of Yazidis in Sinjar (Ridge 2015; Newton 2016; Salih 2016). Palmyra was the perfect target that Daesh was keen to control and brutally destroy to show demonstrate their power as Whitmarsh (2015) has commented, "[Palmyra] offers antiquities' best counterexample to Isis's fantastic monoculturalism" (Whitmarsh 2015).

On the other hand, the tragedy of the last five years is that heritage destruction has appeared to focus on the self-image of the West, Russia and China, and how these global powers have managed this conflict on the political, humanitarian and even cultural sides. After Daesh controlled Palmyra, people started to whisper about a possible Russian military intervention to support the Syrian government army in the combat against "terrorism" in general and Daesh in particular (Lister 2015; Luhn 2015;

\footnotetext{
${ }^{4}$ For further discussion about types of targeted heritage by Daesh, see de Cesari 2015.
} 
Nissenbaum 2015). Four months later, Russia declared that backing the Syrian government to "liberate" Palmyra from Daesh hands was one of their priorities.

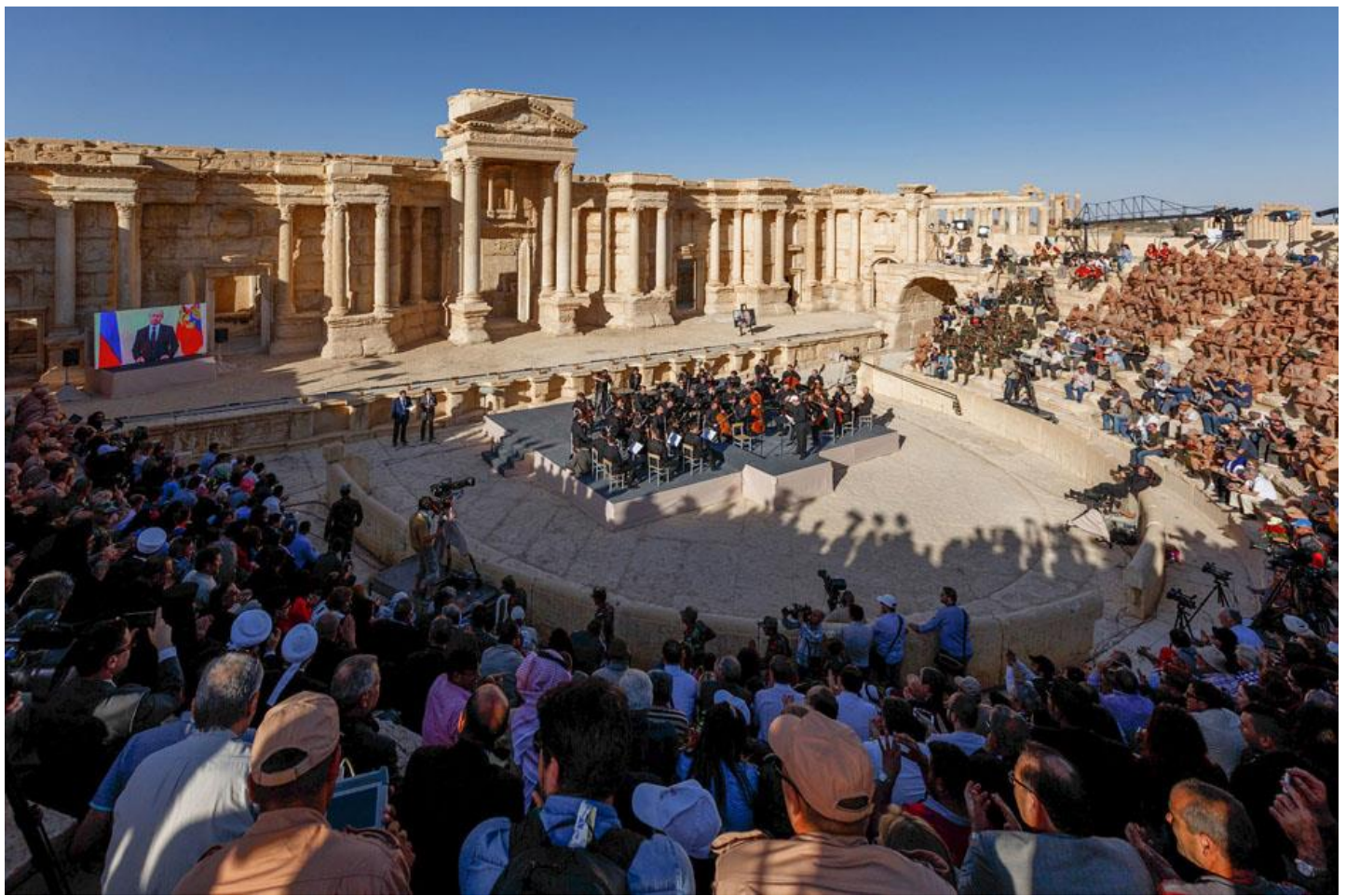

Figure 4. Russian Orchestra and Putin's Speech - Vasily Maximov AFP, Getty Images - 06 May 2016

On March $27^{\text {th }} 2016$, the Syrian army captured Palmyra and liberated it from Daesh (Dearden 2016; Russia Today 2016), but another type of occupation took place by the Syrian and Russian soldiers. Nevertheless, the Syro-Russians celebrated the "liberation" of Palmyra by holding a concert of a Russian Orchestra (BBC 2016; Kramer and Higgins 2016) (Fig. 4). An online speech of Vladimir Putin, President of Russia, was broadcast in the same Roman amphitheatre that Daesh had used - less than 10 months previously before beheading a group of prisoners. Sweeney (2011) believes that heritage is usually utilized during war periods as a weapon in propaganda battles. The latter point was evidenced when media reports in Russia and Syria started to create a huge amount of propaganda about the effectiveness of the Syro-Russian alliance and how the West stood powerless, propaganda that aimed - according to Tim Black (2016) - at asserting that Russia is not just a defender of a tyrant regime in the Middle East but is also the defender of Western civilization, and its values and traditions. It is worth mentioning that Daesh's occupation of Palmyra and the subsequent recapture by the Syrian government forces were caused by the change of powers during the battles in Syria. As Amr Al-Azm, a pro-opposition archaeologist, has worried, any new shift of power during the ongoing war could place Palmyra back in the hands of Daesh (Zorich 2016). By military standards, Palmyra is no more than a strategic location and a place that would provide a considerable amount of media reports and resonating propagandas, which is exactly what Palmyra has witnessed in the last five years of war, moving from one side to another. The site in itself has started to represent a new tendency in the West 
which lately has emerged to try and justify European interest in protecting and reconstructing what Daesh destroyed by claiming that Palmyra's heritage is part of a European heritage. The West - including Russia - sees the heritage of the Near East as being part of "Europe's story" and the origins of the Western civilization (Munawar 2016). This idea has been reinforced by over a century of archaeological investigations by Western archaeologists. Also, Syrian government officials such as Maamoun Abdulkarim, Syria's director of antiquities, stated during the ceremony of erecting the replica of the Arch of Triumph that "[Palmyra's heritage] is not just for Syrian people" (Turner 2016). Today's Western academic writings present what may be termed "charismatic" archaeology - such as Palmyra - as the point at which "Europe ends", ignoring that this heritage not only belongs to Europe, but is originally Syrian, and represents the identity and memories of the local population (for further reading concerning the use of the term "charismatic", see: Ducarme et al. 2013).

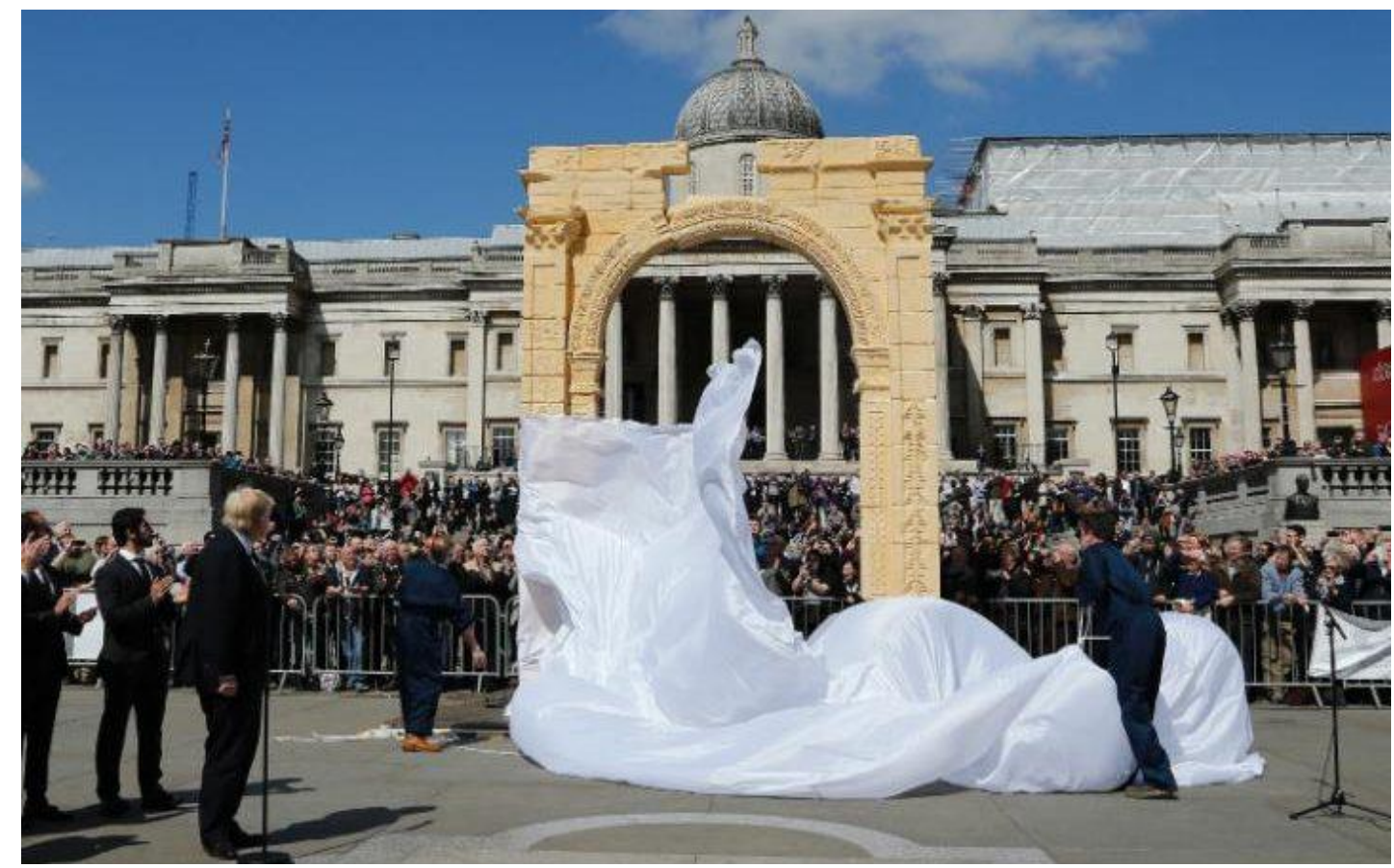

Figure 5. Boris Johnson, the Mayor of London, looks on as the scale replica of Palmyra's Triumphal Arch is unveiled in Trafalgar Square - Frank Augstein AP - The Telegraph - 20 April 2016.

\section{Reconstructing Palmyra: The Way Forward}

The hardest challenge of Palmyra is yet to come since the destruction - as I have argued before - is not all that is threatening Palmyra's heritage. The real test for Palmyra lies in the plans which are being prepared for reconstruction (Harrowell 2016). Conflicts play a major role in changing the urban, social and power structures and meanings can be transformed (Viejo-Rose 2011). With this last point in mind plans for reconstruction offer an opportunity for transformations and new interpretations of heritage, particularly in the aftermath of war when new narratives, legends, and symbols are required to build the nation. Harrowell (2016) believes that destruction and reconstruction are two sides of the same coin, as they both have political goals and exercise powers through and over 
the space. Equally, it is often said that history is written by the victors (Sweeney 2011), particularly in post-conflict contexts. Therefore, the one who has the right to control the reconstruction processes will be the one who decides how Palmyra will be remade.

During the offensive attack to recapture Palmyra, Mikhail Piotrovsky, the Director of the State Hermitage Museum in Saint Petersburg, declared his intention to "rebuild" Palmyra by using the Russian institution's collection of artifacts from Palmyra (Kishkovsky 2016). This shows how significant the reconstruction of Palmyra is, and institutes around the world in places such as in Germany ${ }^{5}$, the $\mathrm{UK}^{6}$, and Russia, have started to make plans, even before the liberation of the World Heritage Site.

The Syrian war has not ended, but the reconstruction of some parts of Palmyra has already commenced. Less than one month after the retaking of Palmyra, a replica of the Triumphal Arch (Fig. 5) had been recreated from Egyptian marble and later erected in London's Trafalgar Square by Oxford's Institute of Digital Archaeology (IDA). The recreation of Palmyra's arch did not reproduce all of the original characteristics of the destroyed arch, such as its height and use of materials and this has generated concerns over the authenticity of monuments. Professor Bill Finlayson, from the Council for British Research in the Levant (CBRL) stated that "the dangerous precedent suggests that if you destroy something, you can rebuild it and it has the same authenticity as the original" (Hopkins 2016).

The "reconstruction" of the Arch of Triumph is similar to the Russian attempt to harness the power of the ancient city by pushing propaganda about which side of the conflict would be best able to reconstruct and rebuild the cultural heritage in the aftermath of the war. Moreover, the replica project has missed several elements which are usually taken into consideration with physical reconstruction after wars. The reconstruction of Palmyra has been tied to issues that surrounded the process of destruction itself, such as cultural identity and collective memory. Harrowell (2016) thinks that the physical rebuilding of Palmyra's monuments can be considered "an act of resistance of the community" which were affected by the conflict. This explains the swift reconstruction of Warsaw's old town which is seen by some people as a "Disney fabrication" (Harbison 2015) and not everyone welcomed the way that Warsaw ultimately turned out. Physical reconstruction is part of post-war recovery and is deeply connected to politics, economy and culture. Simultaneously, reconstructing places in the aftermath of war cannot be separated from the physiological and social reconstruction of the wounded societies (Harrowell 2016).

\footnotetext{
${ }^{5}$ See also, Reconstruction A Network For Archaeological Cultural Heritage. Archaeology Worldwide special issue 2016, German Archaeological Institute (DAI), accessed 21 April 2017, https://www.dainst.org/documents/10180/2082824/Archaeology+Worldwide+Special+Issue+2016/0e 33097d-1071-4c7b-b4dc-85b81a5cb7b2

${ }^{6}$ See also, Triumphal Arch in the News - The Institute for Digital Archaeology in Oxford, UK, accessed 21 April 2017, http://digitalarchaeology.org.uk/media/
} 
After the end of the war in the Balkans, reports indicated that the local population felt disconnected from the reconstruction of their heritage, since they were often not consulted about the reconstruction plans, and specifically, in the case of the Stari Most (the Old Bridge) in Mostar City in Bosnia and Herzegovina (Lostal \& Cunliffe 2016, for further discussion about destruction and reconstruction of heritage in Bosnia and Herzegovina, see Walasek et al. 2016). Furthermore, the conflict can be protracted on a social level and can continue for generations when there is a decision to be made about whether or not to rebuild symbolic sites (Viejo-Rose 2011). The aftermath of reconstruction of cultural heritage can be as destructive as the destruction itself and has the power to prolong violence even after the civil war ends.

Based on these considerations, rebuilding, recreating, restoring or even reconstructing must not be carried out when a war is still ongoing and should not be rushed or controlled by one party, such as the victorious side. Discussions about rebuilding, not only of physical buildings but also the psycho-social wellbeing of communities should only take place when a war ends. Concerns have been raised for Palmyra's fate as people do not want to repeat the Beirut experience, when the reconstruction was mainly focused on the commercial space of Beirut's old town (Nagel 2000). The post-conflict reconstruction of Palmyra should be incorporated into the reconciliation of Syrian society with all its divisions, ethnicities, sectors and religions. Simultaneously, the reconstruction should avoid misuse by people in power and have safeguards to ensure that previous examples of post-civil-war reconstruction which served to support a particular side of the conflict are not repeated, such as the case of Spain after its Civil War (Viejo-Rose 2011) or the Iraqi case (Isakhan 2011) when post-war reconstruction aimed at erasing the Baath identity after the US/UK invasion in 2003.

In my view, no rebuilding or restoration plans can be safeguarded at this stage of Syria's unfinished war and it is wrong to believe that even state or the modern art restoration technologies can in some way replicate or recreate the authenticity of a contested heritage. Authenticity is not only a practical matter or theoretical principal, but requires the inclusion of local stakeholders - regardless of their political stances or geographical distribution - in making decisions as to whether or not to reconstruct. This is needed to ensure that communities feel that they are connected to the future heritage and will serve to enhance the social cohesion of the wounded society. Scholars are mainly concerned with the issue authenticity of space and time in post-conflict contexts and how the relationship between local communities and places can be (re)established. Therefore, the differences and multiple meanings that future heritage could transmit and the mechanisms for remembrance and reconciliation should be carefully included in plans when the time for post-war recovery comes. In this way heritage can have a healing effect and therapeutic influence in the aftermath of war.

\section{Acknowledgements}

This article owes much gratitude to the constructive comments and the continuous support offered by Prof. James Symonds, Dr. Abdulrahman Mnawar and Flavia 
Brunetti, as well as the anonymous reviewers. It is worth to mention that every single minute spent on writing and editing this article, has kept my memory alive and prevented me from forgetting the destructions that I witnessed in Syria. It is difficult to write on heritage ruination while the humanitarian catastrophe continues all over Syria, but perhaps this article can be the first step towards reconnecting locals to their heritage and later healing the war trauma.

\section{References}

ABAZI, E., 2004. The Role of International Community in Conflict Situation. Which Way Forwards?. The Case of the Kosovo/a Conflict. Balkanologie. Revue d'études pluridisciplinaires, 8(1): 9-31.

AFP 2012, Syrie: Palmyre, la cité antique en état de siege. Accessed 09 Nov 2016. http://www.lepoint.fr/monde/syrie-palmyre-la-cite-antique-en-etat-de-siege-19-02-

2012-1432906_24.php

BBC 2015. Islamic State militants "destroy Palmyra statues". Accessed 09 Nov 2016. http://www.bbc.com/news/world-middle-east-33369701

BBC 2016. Russian maestro plays in Palmyra ruins. Accessed 09 Nov 2016, http://www.bbc.com/news/world-middle-east-

36217853?intlink_from_url=http://www.bbc.com/news/topics/45d1e6e1-6001-4449-

801d-ba85eed04025/syrian-civil-war\&link_location=live-reporting-map

BLACK, T. 2016. Russia's Palmyra Concert Reveals What The West Lacks. The Spiked. Accessed 09 Nov 2016. http://www.spiked-online.com/newsite/article/russiaspalmyra-concert-reveals-what-the-west-lacks/18342\#.WBooH4MrLct

BоотH, M. 2011. Constructions of Syrian identity in the Women's press in Egypt, in: A. BESHARA, 2011. The origins of Syrian nationhood: histories, pioneers and identity. Routledge.

Brosché, J., M. LEgnér, J. KREUTZ \& A. IJLA, 2017. Heritage under attack: motives for targeting cultural property during armed conflict. International Journal of Heritage Studies 23(3): 248-260.

Cunliffe, E., 2012. Damage to the soul: Syria's cultural heritage in conflict. Palo Alto: Global Heritage Fund.

DeARDEN, L. 2016. Isis 'losing control' of Palmyra as Syrian troops backed by Russian air strikes approach ancient city. The Independent. Accessed 09 November 2016. http://www.independent.co.uk/news/world/middle-east/isis-losing-control-of-

palmyra-as-syrian-troops-backed-by-russian-air-strikes-approach-ancient-citya6953921.html

De CeSARI, C., 2015. Post-Colonial Ruins: Archaeologies of political violence and IS. Anthropology Today 31(6): 22-26.

DonNer, F.M., 2014. The early Islamic conquests. Princeton University Press.

DuCARMe, F., G.M. LuQue \& F. COURCHAMP, 2013. What are "charismatic species" for conservation biologists. BioSciences Master Reviews 10(2013): 1-8. 
GERMAN ARChAEOLOGICAL InSTITUTE, 2016. Reconstruction a Network For Archaeological Cultural Heritage. Archaeology Worldwide special issue 2016. Accessed 21 April 2017.

https://www.dainst.org/documents/10180/2082824/Archaeology+Worldwide+Special +Issue+2016/0e33097d-1071-4c7b-b4dc-85b81a5cb7b2

HALL, J. 2015. ISIS 'destroys' famous lion god statue in captured Syrian city of Palmyra...just days after promising locals they would not obliterate ancient monuments. The Dailymail. Accessed 09 Nov 2016.

http://www.dailymail.co.uk/news/article-3101031/ISIS-destroys-famous-lion-god-

statue-captured-Syrian-city-just-days-promising-locals-not-obliterate-Palmyra-s-ancientmonuments.html

HARBISON, R., 2015. Ruins and Fragments: Tales of Loss and Rediscovery. Reaktion Books. HARMANŞAH, Ö., 2015. ISIS, Heritage, and the Spectacles of Destruction in the Global Media. Near Eastern Archaeology 78(3): 170-177.

HARRISON, R. (ed.), 2010. Understanding the politics of heritage (Vol. 5). Manchester: Manchester University Press.

Harrowell, E., 2016. Looking for the future in the rubble of Palmyra: Destruction, reconstruction and identity. Geoforum 69: 81-83.

Hausler, K., 2016. Culture under Attack: The Destruction of Cultural Heritage by Non-State Armed Groups. Santander Art and Culture Law Review (2): 117-146.

Holmes, O. 2013. Syria's ancient oasis city of Palmyra threatened in fighting. Reuters. Accessed 09 November 2016.

http://www.reuters.com/article/us-syria-crisis-palmyra-idUSBRE9320HL20130403

HOLTORF, C., 2015. Averting loss aversion in cultural heritage. International Journal of Heritage Studies 21(4): 405-421

HopkIns, S. 2016. Palmyra's Arch of Triumph Recreated In London's Trafalgar Square in 'Triumph of Human Ingenuity over Violence'. Huffington post UK. Accessed 25 August 2017. http://www.huffingtonpost.co.uk/entry/palmyras-arch-of-triumph-recreated-inlondon_uk_57160ae1e4b0dc55ceeb0181

HubBard, B. 2015. Syrian Expert Who Shielded Palmyra Antiquities Meets a Grisly Death at ISIS' Hands. New York Times. Accessed 22 August 2017. https://www.nytimes.com/2015/08/20/world/middleeast/isis-palmyra-syria-

antiquities-scholar-beheaded.html?mcubz $=1$

IsAKHAN, B., 2011. Targeting the symbolic dimension of Baathist Iraq: cultural destruction, historical memory, and national identity. Middle East Journal of Culture and Communication 4(3): 257-281.

Kealy, L., 2016. Post-Trauma Reconstruction. Proceedings of the 1-day Colloquium at Icomos Headquarters, 4 March 2016. Volume 1 and 2 . Conference Volume. ICOMOS International Secretariat, Charenton-le-Pont, Franc.

KishKOvSKY, S. 2016. 'This is living antiquity': the director of the Hermitage wants to rebuild Palmyra. The art newspaper. Accessed 09 November 2016. http://theartnewspaper.com/news/museums/this-is-living-antiquity-the-director-ofthe-hermitage-wants-to-rebuild-palmyra/?platform=hootsuite Kramer, A. \& A. Higgins, 2016. In Syria, Russia Plays Bach Where ISIS Executed 25. New York Times. Accessed 22 Aug 2017. 
https://www.nytimes.com/2016/05/06/world/middleeast/syria-russia-palmyra-isisclassical-music.html?mcubz $=1$

LisTER, T. 2015. Why Russia is pressing the 'accelerate' pedal in Syria. CNN. Accessed 21 April 2017.

http://edition.cnn.com/2015/10/15/middleeast/russia-syria-hardware-lister/

Lostal, M. \& E. CunLIFFe, 2016. Cultural heritage that heals: factoring in cultural heritage discourses in the Syrian peacebuilding process. The Historic Environment: Policy \& Practice 7: 1-12.

LuHN, A. 2015. Russia sends artillery and tanks to Syria as part of continued military buildup. The Guardian. Accessed 21 April 2017. https://www.theguardian.com/world/2015/sep/14/russia-sends-artillery-and-tanks-tosyria-as-part-of-continued-military-buildup

MACFARLAN, T. 2015. Wiping yet more history off the face of the earth: ISIS blow up 2,000-year-old Temple of Bel in Palmyra in latest outrage at the ancient Syrian city. The Dailymail. Accessed 09 November 2016. http://www.dailymail.co.uk/news/article3216360/ISIS-blow-2-000-year-old-Temple-Bel-Palmyra-Syria.html\#ixzz4PWz8sIsC

Melvin, D., S. Elwazer, J. Berlinger, 2015. ISIS destroys Temple of Bel in Palmyra, Syria, U.N. reports. CNN. Accessed 22 August 2017. http://edition.cnn.com/2015/08/31/middleeast/palmyra-temple-damaged/index.html MASON, R., 2002. Assessing values in conservation planning: methodological issues and choices, in: M. de la Torre (ed.) Assessing The Values Of Cultural Heritage. Research Report, The Getty Conservation Institute, Los Angeles, 5-30.

MeskelL, L. 2005. Sites of violence: Terrorism, tourism, and heritage in the archaeological present, in: L. Meskell \& P. PELS (eds), Embedding ethics. Oxford: Berg, 123-146.

NEWTON, J. 2016. ISIS burn 19 Yazidi girls to death in iron cages after they refused to have sex with jihadists. The Dailymail, accessed 09 November 2016, http://www.dailymail.co.uk/news/article-3627063/ISIS-burn-19-Yazidi-girls-deathiron-cages-refused-sex-jihadists.html

O'CONNOR, M. P. (1988). "BCILL 42: Linguistic Happening, the etymologies of Tadmor \& Palmyra", in: Y.L. ArbeITMAN (ed.), A linguistic bappening in memory of Ben Schwart: Studies in Anatolian, Italic, and other Indo-European Languages, Louvain-la-Neuve, 411-462.

PECHT, M. 2016. International responses to ISIS (and why they are failing), accessed 23 April 2017, Stockholm International Peace Research Institute https://www.sipri.org/commentary/essay/2016/international-responses-isis-and-whythey-are-failing

RIDGE, S. 2015. Mass graves of women 'too old to be Isil sex slaves' - this is what we're up against. The Telegraph, accessed 09 November 2016, http://www.telegraph.co.uk/women/womens-politics/12000148/Islamic-State-sexslaves-Sinjar-mass-graves-show-what-were-fighting.html

SALIH, M. A., 2016. The horrors of a Yazidi woman kidnapped by ISIS. Washington post, accessed 22 August 2017, https://www.washingtonpost.com/opinions/thehorrors-of-a-yazidi-woman-kidnapped-by-isis/2016/08/18/0a7c655e-2edb-11e6-9b3742985f6a265c_story.html?utm_term=.e1ed088bcb5d 
SHAHEEN, K. 2015A. Beheaded Syrian scholar refused to lead Isis to hidden Palmyra antiquities. The Guardian, accessed 09 November 2016, https://www.theguardian.com/world/2015/aug/18/isis-beheads-archaeologist-syria SHAHEEN, K. 2015b. Isis 'controls 50\% of Syria' after seizing historic city of Palmyra. The Guardian. Accessed 09 November 2016. https://www.theguardian.com/world/2015/may/21/isis-palmyra-syria-islamic-state Turner, L. 2016. Palmyra's Arch of Triumph recreated in London. BBC, accessed 09 November 2016, http://www.bbc.com/news/uk-36070721

Munawar, N. A. 2016. Can Local People Preserve Cultural Heritage? Paper presentation at the $22^{\text {nd }}$ annual meeting of the European Association of Archaeologists in Vilnius, Lithuania in 2016.

NAGLE, C., 2000. Ethnic conflict and urban redevelopment in downtown Beirut. Growth and Change 31(2): 211-234.

NAKASIS, A. \& LIANOS, N. 2015. Syria: The Impact of the Civil War on the Cultural Heritage. In ICOMOS (ed.), Heritage at Risk: World Report 2011-2013 On Monuments and Sites In Danger, Berlin, 143-147.

Nissenbaum, D. 2015. Months of Airstrikes Fail to Slow Islamic State in Syria. The Wall Street Journal, accessed 21 April 2017. https://www.wsj.com/articles/u-s-led-airstrikesfail-to-slow-islamic-state-in-syria-1421271618

RUSSIA TODAY, 2016. Syrian army retakes Palmyra from ISIS. Accessed 09 November 2016. https://www.rt.com/news/337336-palmyra-syrian-army-isis/

Sørensen, M.L.S. \& D. VIEjO-Rose (eds.), 2015. War and Cultural Heritage. Cambridge University Press.

SWEENEY, S., 2011. Book Review: Reconstructing Spain: cultural heritage and memory after civil war by Viejo-Rose, D. International Journal of Heritage Studies: 17(6), 629-631.

TEIXIDOR, J., 2015. The pagan god: popular religion in the Greco-Roman Near East. Princeton University Press.

Tharoor, I. 2015. Islamic State destroys priceless statues in ancient city of Palmyra. Washington post, accessed 22 August 2017.

https://www.washingtonpost.com/news/worldviews/wp/2015/07/03/islamic-statedestroys-priceless-statues-in-ancient-city-of-palmyra/?utm_term=.adb3223e98b1

UNESCO 2013. Syria's Six World Heritage sites placed on List of World Heritage in Danger. Accessed 23 April 2017. http://whc.unesco.org/en/news/1038/

UNESCO 2014. UNESCO Director-General condemns military presence and destruction at World Heritage Sites in Syria. Accessed 23 April 2017.

http://whc.unesco.org/en/news/1108/

VIEJO-ROSE, D., 2011. Reconstructing Spain: cultural heritage and memory after civil war. Apollo Books.

WALASEK, H, 2016. Bosnia and the destruction of cultural Heritage. Routledge.

Whitmarsh, T., 2015. Tolerant and multicultural, Palmyra stood for everything Isis hates. The Guardian, accessed 09 November 2016.

https://www.theguardian.com/commentisfree/2015/aug/25/palmyra-tolerant-

multicultural-isis-ancient-city-migrants-savagery 
Wintour, P., 2016. Isis destruction of Palmyra antiquities revealed in new pictures. The Guardian, accessed 09 November 2016.

https://www.theguardian.com/world/2016/apr/01/isis-destruction-of-palmyraantiquities-revealed-in-new-pictures

ZORICH, Z., 2016. Tallying the losses in Palmyra. Science 352(6282): 130-131. 